\title{
Politics of prevention in the periphery: The initial response to COVID-I 9 on Barbuda and Puerto Rico
}

\author{
Sophia Perdikaris \\ University of Nebraska, Lincoln \\ sperdikaris2@unl.edu (corresponding author) \\ Roberto Abadie \\ University of Nebraska, Lincoln \\ rabadie2@unl.edu \\ Edith Gonzalez \\ University at Buffalo - State University of New York \\ egon5@buffalo.edu \\ Emira Ibrahimpašić \\ University of Nebraska, Lincoln \\ emira@unl.edu
}

\begin{abstract}
The islands of Barbuda and Puerto Rico share a history of dispossession and exploitation, occupying a peripheric position in a core-periphery world system. Yet, each island's response to COVID-19, and the subsequent effects of the pandemic, could not be more different. This paper examines how colonialism and neocolonialism affected the islands' ability to respond to COVID-19. Barbuda relied on community traditions of support and self-reliance and was able to restrict all travel to and from the island, including travelers from the diaspora and those participating in its informal economic sector. In doing so, Barbuda effectively isolated itself from infection. On the other hand, Puerto Rico, in a protracted economic crisis, was particularly vulnerable to touristic flows, diasporic movements, and a large informal sector. The Puerto Rican response was shaped by deep politicization in the mainland U.S., which complicated an evidencebased strategy to combat the emergency. These cases show that islands, particularly those located in peripheric or subaltern spaces, cannot isolate themselves from the worst effects of COVID-19 through mere geography. Pandemics are not only driven by biological events but also by the narratives of colonialism, encompassing political, economic, and cultural factors, which determine their trajectories — sometimes with devastating outcomes.
\end{abstract}

Keywords: Barbuda, COVID-19, health disparities, islands, neocolonialism, Puerto Rico.

https://doi.org/10.24043/isj.381 • Received August 2021, Early access February 2022

(C) Island Studies Journal, 2022 


\section{Introduction}

In September of 2017, a series of devastating hurricanes hit the northern Caribbean with deadly force. Two islands were particularly hard hit when Category 5 storms - Maria and Irma made direct landfall on Puerto Rico and Barbuda, respectively, within two weeks of one another (Cruz-Cano \& Mead, 2019; Kane, 2018). In the aftermath of the storms, the two islands were isolated and effectively cut off from outside assistance. Both islands have a culture of strong community bonds and, for many, the immediate, localized community action was the difference between life and death (Boger \& Perdikaris, 2019). While an extreme climatic event, such as a hurricane, appears as discrete, it lays bare the ongoing challenges in a region that has moved from colonial to neocolonial realities and that faces the predatory actions of a global elite using the effects of natural crisis to further capital accumulation - or what Naomi Klein (2007) has termed "disaster capitalism." Still recovering from the destruction brought by natural disasters, the islands were forced to address the challenges of an emerging pandemic. Throughout this paper, we will discuss Puerto Rico and its peripheric relationship to the mainland U.S., and Barbuda, which is the sister island of Antigua in the nation of Antigua and Barbuda. Although Antigua will inevitably be mentioned as the core of the two-island nation, the focus of this paper is on peripheric Barbuda, whose local culture, political structure, and responses to crises differ greatly from that of Antigua. The intention of this paper is to capture the initial response on both islands to the emergence and spread of COVID-19. The observations of the authors, made through onisland interviews, personal communications, and academic research, reflect a particular moment in time, which has altered since then as the situation continues to shift and reshape.

In December of 2019, the first COVID-19 cases appeared in Wuhan, China and quickly spread - reaching global pandemic proportions within three months and sparing no territory or population. Barbuda and Puerto Rico were impacted by the arrival of COVID-19 that disrupted central aspects of their social organization (Johns Hopkins University and Medicine, 2021a,b). Yet, the responses to the pandemic varied significantly among the islands. We suggest that in order to understand the differentiated social responses to COVID-19, it is important to consider the 'politics of prevention'. The phrase politics of prevention describes cultural and political phenomena and structures that impact preventive initiatives related to disease and injury (Goldstein \& Engwall, 1992; Mykhalovkly \& French, 2020; Romano, 2020). Politics of prevention include larger issues such as: which kind of 'knowledge' will be the defining source for guiding the implementation of a response strategy? And who will be the decision makers choosing the interventions and selecting who will be affected and who will be spared?

This paper examines the public health responses to the COVID-19 pandemic and explores the inequalities faced by residents of both islands. It argues that the response to the pandemic cannot be disentangled by the peripheric positions of Barbuda and Puerto Rico in the world system, Barbuda in relationship to Antigua, and Puerto Rico in relation to the mainland U.S., which deprives the islands of the resources to respond to a health crisis and exposes their populations to COVID-19 through migration, tourism, and the needs to support an informal economy. Immanuel Wallerstein's (1974) model of world-systems theory can be applied in this case to explain the economic and health disparities witnessed historically and today. The theory 
posits that there is one world economy; within this model of global capitalist accumulation, a country at the core of power has the ability to set market prices, wages, and the economic agenda, and - perhaps most important to this case - they can control their borders (Wallerstein, 1974).

In the Caribbean, throughout the ages, people have had to adapt to ongoing challenges of drought, war, hurricanes, and, most recently, plague. COVID-19 challenged the social organization of the islands, bringing into the open the ways in which their colonial and postcolonial status shaped their ability to respond to an emerging crisis. Tourism, diasporic migration, and informal economies in the context of the politics of prevention come down to two factors: the flow of money and the flow of people between the core and periphery. It is obvious how tourism contributes to economy and the flow of people (and potential infections) to an island but diasporic migration and informal economies also create a similar influx of funds and people. The globalized economy, the outward and transnational orientation of the inhabitants of the Caribbean, and its external dependency, have had the effect of a steady out-flow of migrants to North America and the former colonizers of Western Europe (Thomas-Hope, 2002). In the words of Thomas-Hope (2002, p. 16):

Migration has traditionally been viewed in the Caribbean as the proverbial 'safety valve' that allows any surplus of people in the labor force to leave the country in search of work rather than cause an unbearable build-up of societal tensions.

Specifically, the nation of Antigua and Barbuda's dependence on its informal sector is due to the tax burden which, at 40\%, is among the highest in the Caribbean (Vuletin, 2008, p. 14). Meanwhile, in Puerto Rico, it is estimated that up to one in three jobs belong to the informal economy (Setser \& Maruach, 2020).

As we reflect on the initial impacts of the COVID-19 pandemic one year later, we observe how it has reconfigured key aspects of social organization, economies, and politics, and touched all of our lives. How did the pandemic affect Barbuda and Puerto Rico? How have these coreperiphery relationships been manifesting themselves with these added cumulative challenges? In returning to our previous work on Barbuda and in Puerto Rico, we again see how the strong culture of community is playing out, but in different contexts.

Despite the similarities of experience between the islands after the storms, their experiences as the COVID-19 pandemic continues to rage show the critical ability to make self-determined and community-driven decisions as a key factor to survival. The devastation caused by COVID19 cannot be understood as the product of virological activity alone. Instead, this pandemic, like others before, elicited contrasting social responses with quite different outcomes, illustrating how economic, political, and cultural factors shaped the pandemic trajectory. This is a conceptual paper from island perspectives, taking a longue durée approach from the colonial past to the present.

\section{COVID-19 and the politics of prevention}

The first case of COVID-19 in Barbuda was identified in January of 2021 (Barbuda Council, 2021a; "First positive Covid-19 case recorded", 2021), and five additional cases were identified 
the following month (Barbuda Council, 2021b). At the time of writing, the first documented case on-island was one Barbudan citizen visiting from the U.S., while the remaining five positive cases were foreign workers - part of the crew for the Ocean Club construction projects. Barbuda has been under a strict mask mandate from the early days of the pandemic, as well as a curfew which, up until March of 2021, was from 6PM to 5AM. COVID-19 testing has been ongoing at the Hanna Thomas Hospital in Codrington, and local doctors have been vigilant about quarantining and following up on anyone who has symptoms. One of the things that worked to Barbuda's benefit, beyond the generalized government efforts, was the watchful oversight of the Barbuda Council and the fact that, in a small community, everyone knows everyone. In effect, Barbuda's community became its own pod. There is no anonymity on a small island, which allowed the community to quickly identify those who were exhibiting symptoms, help them self-quarantine, provide support, and get them care. The visibility of citizens to one another was to the benefit of Barbuda. On the other hand, its sister island of Antigua has seen significant levels of infection and spread, since it has a larger and more dense population, making community spread much harder to track. With no systematically organized testing, we will never know the actual picture of COVID-19 spread on Antigua in the beginning months of the pandemic. Antigua and Barbuda nationals that travel abroad and return are put on mandatory quarantine, and contact tracing is well organized. In all cases, people are asked to report symptoms daily. On the other hand, tourists who can afford to stay at a COVID-19-certified facility (Antigua and Barbuda Tourism Authority, 2021) can visit with a proof of a negative test and remain on either island practically quarantine-free. In the case of Barbuda, that is not much of an issue, since there are limited shops that would be of interest to tourists, and accessibility to heritage sites or restaurants is still prohibited. The three 'COVID-19 Approved Hotels' on Barbuda are not in the proximity of the island's only village, and there has only been a handful of guests during the entire pandemic so far. While troublesome for the hotels, Barbuda has never depended on tourism as its primary income. Barbudans have experienced curfew, a shift to on-line classes at the local schools, and the expected social distancing/mask mandate but, other than that, little has changed.

In Antigua, however, the difference in treatment between locals and tourists is much more challenging, as tourists in much larger numbers visit local stores and sites and interact with hotel staff who might or might not be vaccinated. The Antiguan economy is so heavily reliant on the tourist industry that the central government was willing to make exceptions: it allowed people who could afford to stay in expensive establishments something called a "flexible quarantine" under which tourists may "enjoy the advertised offerings" of Antigua, including excursions beyond the hotel property (Antigua and Barbuda Tourism Authority, 2021). While the government sets the COVID-19 protocols for tourism, it is up to the hotel to enforce them creating a conflict of interest for hotels trying to survive. The same privilege of 'flexible quarantine' is not afforded to residents, who must quarantine at home (Antigua and Barbuda Tourism Authority, 2021). This is a direct statement about needing foreign funds, but at what cost? The mono-economy of tourism increases vulnerability of island nations and forces governments to choose between crashing economy and public health. 
In the case of Puerto Rico, the first cases of COVID-19 were identified on the island the week of March 9-13, 2020 (Valencia et al., 2020). In response, following a script already enacted in the continental U.S., the governor promptly declared a state of emergency and implemented a curfew, issuing stay-at-home orders and limiting non-essential business operations and air travel. In addition, public and private schools were suspended at all educational levels, and governmental agencies closed. Following recommendations from the Center of Disease Control, COVID-19 cases were identified and isolated and their contacts were quarantined for 14 days. State of emergency measures were adopted and relaxed according to the progression of COVID-19, in an effort to balance economic consideration with public safety (Miranda, 2020).

Further, the subaltern position of Puerto Rico in relation to the U.S. placed additional burdens in organizing an effective response to the pandemic. The outsized dependence of the island on tourism, the movements of the Puerto Rican diaspora, and an extensive informal economy provided a terrain for viral dispersion while limiting the effectiveness of the measures adopted to manage the pandemic. Puerto Ricans were ambivalent about the arrivals of touristic flows after the first cases of COVID-19 were detected on the island. Some feared that tourists coming from states severely affected by COVID-19, like New York or Florida, could bring the disease to the island. Headlines depicting tourists without masks or disrespecting social distancing requirements contributed to the perception that tourists acted as if they "owned" (C. Murphy, 2021) Puerto Rico and did not care about their residents. On the other hand, tourist-dependent businesses adopted a more welcoming approach, suggesting the need to balance public health with economic interests.

As the above discussion demonstrates, the impact of the pandemic has been different on the two islands but, in both cases, the COVID-19 narrative exposes health disparities and the differential treatment of locals and visitors.

\section{Historical dimensions of Barbuda and Puerto Rico and the role of tourism}

Historically, both Barbuda and Puerto Rico have long been under the yoke of colonialism and continuing neo-colonialism (Garriga-López, 2018, 2020; LeBrón, 2012), particularly as the World Bank identified the Caribbean as a region of tourism and service just after WWII, and it is important to understand the effects that this has on identity and community culture.

\section{Barbuda}

Barbudan culture reaffirms traditional ecological knowledge and community relationships rather than production and consumption. This is even more salient as the vulnerability of the island to outside development, encroachment on long-standing cultural traditions, food security, and sustainability has been laid bare since Hurricane Irma in 2017. In the realm of public health, however, the community-centered culture has been a strength. Barbuda is one of the northernmost islands in the archipelago of the Lesser Antilles in the Eastern Caribbean and has been occupied for over 5,000 years, from prehistoric to contemporary times (Look \& Brown, 2007; R. Murphy, 1999; Newsom \& Pearsall, 2003; Newsom \& Wing, 2004; Perdikaris et al., 
2013; Watters, 1992). A consistent strategy for facing these challenges has been the development of a culture grounded in community-based decision making.

Barbuda became a British colony in 1632 and, in 1674, a family with large holdings in Barbados and Antigua (the Codrington family) received an exclusive lease issued by the Crown to exploit the entire island. This lease extended until 1898. After failed attempts to use Barbuda for large-scale, mono-crop cultivation, the Codringtons primarily used Barbuda as provisioning source for their sugar estates on Antigua and for local export. Provisions and resources cultivated on Barbuda included salt, livestock (horses, cows, sheep, and chicken), and ground provisions like Irish potatoes and cassava (Gonzalez-Scollard, 2008). Over the course of the Atlantic Slave Trade, more that 80,000 people were sold into bondage and sent to Antigua \& Barbuda. In any given year between 1674-1835, approximately 300-500 enslaved people of African descent lived and worked on Barbuda, cultivating introduced agricultural species from the four corners of the British Empire. These enslaved small farmers brought their knowledge of landscape, agriculture, and animal care to Barbuda, creating a sustainable, land-based lifestyle. Their traditional, open cattle grazing methods fared better than the enclosed, private pastoral methods typically used by colonial regimes (Potter \& Sluyter, 2010). In the extensive collection of colonial estate records from the Codrington family, letters from the appointed managers at Barbuda indicated that the people held enslaved there felt that the land was their own. One manager on Barbuda, R. Jarrit, wrote in 1820 that the people living and working on Barbuda "acknowledged no master, and believe the island belongs to themselves." Barbudans were isolated from Antigua, by decree of the landowner, throughout most of the 18th century and up to emancipation in 1834. During this time, Barbudans developed their own informal economy; for example, poachers, farmers, and fishermen would trade venison, vegetables, and fish, respectively, for services from the local doctor, carpenter, or seamstress (Codrington Papers 1681-1944). The agricultural practices of experimental botany and provision farming necessitated a vastly different life between Barbuda and the sugar cane plantations of Antigua. The community of enslaved people on Barbuda, while still living under the horrors of slavery, had relative daily autonomy and freedom of movement around the island to work fields and fish (Codrington Papers 1681-1944).

Over time, Barbudans have developed a system of Traditional Ecological Knowledge (TEK), which includes an annual period of "living off the land" (Perdikaris et al., 2017), and is their dynamic way of understanding themselves in relation to the natural environment. TEK includes not only hunting, fishing, and gathering, but stewardship of wild sources of food, ethnobotany, herbal medicine, and agricultural practices developed to the specific soils and seasons of the island. This system of knowledge of the local flora, fauna, weather, landscape, and seascape is passed down intergenerationally and creates a strong culture of community, which has sustained Barbudans through periods of slavery and emancipation, shifting transfer of political power, devastating environmental phenomena — including 2017's Hurricane Irma - and our current global challenge of the COVID-19 pandemic (Bain et al., 2017; Kincheloe \& Semali, 1999).

Since the period of British rule, the community-driven relationship with the land has been maintained through a communal land tenure system. In 1904, Parliament granted Barbudans 
Crown tenant status, which in this case means an occupier of Crown lands on agricultural lease in perpetuity granted under the Land Acts. One of the main outcomes of the post-WWII reconstruction was the new global economic order that favored Global North over the Global South. The World Bank, as the primary tool of neoliberal colonial expansion, relegated the Caribbean, including Antigua and Barbuda, to service economy, mainly tourism and financial services (Collins, 2008, p. 1295). Throughout this period, Barbudan citizens continued to see the land as their own, even as the islands of Antigua and Barbuda integrated into one nation in 1981 and any Crown land was transferred into the ownership of the Antiguan and Barbudan government. In 1981, Antigua and Barbuda gained its independence from England. Even though Antigua and Barbuda were emancipated as one nation, Barbuda has a representative in the parliament in Antigua and has a local governing body — separate from Antigua - called the Barbuda Council.

The Barbuda Land Act of 2007 formally acknowledged that all people in Barbuda owned the land collectively. The island has approximately 1,700 citizens, about half of which are children. Any citizen over the age of 18 has the right to occupy residential land, graze animals, and use land for commercial purposes, as long as projects are not considered major developments. While many Barbudans have extended family in Antigua, the independence and separateness of the two islands has been maintained, both economically and culturally. Barbuda's unique political structure within the Caribbean required that the majority of citizens must vote to support a major development project for a land lease to be granted. 'Major developments' were defined as significantly effecting the island's economy, infrastructure, or environment. This has resulted in very few major developments gaining approval in the last 40 years. Until recently, Barbuda had not undergone the wholesale exploitation of its natural resources to serve the tourism industry as so many other islands have done (Perdikaris \& Hejtmanek, 2020). At present, tourism is the largest economic activity in the two-island nation, accounting for approximately 70\% of GDP and providing around 40\% of overall employment (Potter et al., 2017). Tourism statistics are misleading, however, because they primarily reflect tourism on Antigua. Most of Barbuda's tourism attracts only a small number of tourists - and generally those with very deep pockets (Potter et al., 2017). The repeal of the Barbudan Land Act in 2017 by the Antigua and Barbuda Senate has effectively rendered Barbuda a construction site for further tourist development projects. With the repeal, development projects no longer need the approval of the Barbuda Council, nor do Barbudans have the right to vote on proposed projects. All land deemed unoccupied becomes the property of the central Antiguan government and eligible for private sale or lease to outside interests. Despite the repeal of the land tenure Act (Perdikaris et al., 2020), the commitment of Barbudans to their community and one another remains unchanged.

In light of the COVID-19 pandemic, Barbudans were able to rely on their local collective community to protect their island from external threats. Unlike Antigua, whose economy relies heavily on tourism, Barbuda was able to 'close the door' and quickly restrict access to the island. Like many small communities, Barbudans look out for one another, but in the process of looking out for one's neighbors, everyone is visible and held accountable. This allowed people who were showing symptoms to be quarantined and cared for, and those who were potentially exposed to 
be traced and monitored to prevent spread. The community-minded focus made citizens put the health of others ahead of their individual needs.

As of April 2021, there had been 1,232 documented cases of COVID-19 in Antigua (Reuters, 2021). The reality for Antigua is vastly different to that of Barbuda. Antiguan policies were reactive rather than proactive when it came to organized and widespread testing of people on island (Centers for Disease Control and Prevention, 2021). To date, there have been only five known cases of COVID-19 in Barbuda, including a U.S. visitor and foreign workers for the construction of the new hotel under development. The swift action of the Barbuda Council identified, informed, and quarantined these individuals off-island, effectively cutting off the spread to Barbuda. The disparity of reaction to COVID-19 between Barbuda and Antigua is a function of their political relationship of core-periphery. Generally speaking, the core is the center from which benefits can be tightly controlled and doled out to a peripheral island. In this case, the categories of core and periphery are somewhat flipped - while Antigua retained the decision-making power to 'reopen' the economy, Barbuda was protected by its ability to distance itself from the core. Isolation was a protective mechanism completely within Barbudan control, which is unusual for a peripheral entity.

\section{Puerto Rico}

Puerto Rico has a core-periphery construct with the mainland United States. In 1949, Hilton opened the first luxury hotel in Puerto Rico, located in San Juan. Twenty years later, the Puerto Rican Tourism Company (PRTC) was established to promote tourism. In 2015, with 3.5 million arrivals, the island occupied second place in tourist visits in the Caribbean after the Dominican Republic. San Juan is one of the largest cruise-ship ports in the Caribbean with 1.5 million visitors each year, and one of the busiest airports with almost 9 million passengers annually (Duany, 2017). Nine out of ten passengers who are not of Puerto Rican descent come from the mainland U.S., in the form of 'snowbirds' and spring breakers. However, a considerable number of visitors are from the Puerto Rican diaspora living on the mainland.

Puerto Rico is a former Spanish colony and became a United States possession in 1898 after the U.S. invasion of the island during the Spanish-Cuban-American War. The political status of Puerto Rico has been contested ever since. Initially, the U.S. Supreme Court defined Puerto Rico as "foreign to the United States in a domestic sense" - neither a state of the union, nor a sovereign republic (Burnett \& Burke, 2001). Puerto Ricans were granted U.S. citizen status in 1917 and were immediately drafted to fight in WWI, but the island remained an incorporated territory of the United States (Thomas, 2010; Thompson, 2010). In 1952, the island became a U.S. Commonwealth, with the federal government retaining jurisdiction over most issues of state (Rivera-Ramos, 2001). In practice, this arrangement has afforded the island's residents a secondclass status that even today does not include political rights. Puerto Ricans can elect their Governor

and a resident commissioner in the U.S. Congress, who has a voice but not voting rights. Although Puerto Ricans living on the island have no right to vote for the U.S. President, as U.S. citizens, Puerto Ricans in residence on the mainland have full voting rights (Thomas, 2010). 
Under Spanish colonization, the Indigenous people of Puerto Rico, the Taino, were all but annihilated within a few decades of Christopher Columbus's arrival in 1493. Slavery conditions imposed by the encomienda system of forced labor and diseases like smallpox and measles - for which native populations had no previous exposure and therefore no immunity - reduced a population numbering in the hundreds of thousands to simply hundreds (Pico, 2006). To replace the dwindling Taino labor force, the Spanish colonizers introduced enslaved Africans as the foundation of the sugar industry not only in Puerto Rico, but across the Caribbean, including Antigua (Figueroa, 2005).

At the time of the initial U.S. occupation of Puerto Rico, the island was still predominantly an agricultural society, based on the exports of sugar, tobacco, and coffee (Mintz, 1985). Within a few decades, Puerto Rico had become most reliant on sugar production, with a high concentration of land and capital investment, capitalist relations of production, lack of economic diversification, and the production of a monoculture for a single global market. Unfortunately, the sugar industry suffered the shocks of the economic crisis in 1929 and never recovered (Mintz, 1974). This caused displaced agricultural workers to move from rural areas to more dynamic urban centers. In 1899 less than $8 \%$ of the population lived in cities, by 1950 one in four inhabitants were city dwellers (Ayala \& Bernabe, 2009). Urban population growth was driven by an accelerated process of industrialization after WWII. Industrial incentives lured mainland U.S. industries to the island, offering the highest rates of profit in the Americas. For the next two decades, Puerto Rico enjoyed remarkably high rates of economic growth, averaging 6.8\% in the 1960s based on light manufacturing such as textiles and apparel. The 1970s saw a shift to capital-intensive oil refining and petrochemical industries, and a third shift in the 198's incentivized high technology production, mainly in the pharmaceutical industry and financial services (Dietz, 2003).

The economy then began showing signs of stress, with declining growth rates $3.1 \%$ in 1970 and 2.1\% in 1980). The end of financial incentives in 2006, along with the global capitalist crisis in 2008, placed this extractivist economic model and its reliance on the U.S. in question. By 2017, the island was forced to declare bankruptcy and was put under the administration of a fiscal board by the U.S. Congress (Villanueva et al., 2018). In this context, Puerto Rico has placed its bet on the tourism industry to revitalize its economy; this sector represented almost 7\% of the island GDP and accounted for $7.1 \%$ of the employment. Unfortunately, Zika virus, Hurricane Maria, and the effects of COVID-19 have slowed this growth (Sheller, 2020). In Puerto Rico, several factors complicated its approach to the pandemic. COVID-19 hit the continental U.S. during an electoral year, so that the pandemic and its response were quickly politicized along partisan lines (S. Hart et al., 2020). Business closures, school interruptions, and even masks became objects of political contention. With the governorship and senate, house, and municipal positions at stake, the government had an interest in showing results in the fight against COVID-19 but needed to balance public health restrictions against the need to support an economy already on life support after years of stagnation (García et al., 2020).

Tourism has been an important economic development tool for many parts of the world (Pan American Health Organization, 2021). While tourism activities have significantly declined since the start of the COVID-19 pandemic, global tourism had unprecedented growth in the years prior. In 2019, the global tourism industry contributed 9.17 trillion USD to the global 
economy, accounting for over 10\% of global GDP, and saw about 1.46 billion travelers (World Travel and Tourism Council, 2021). While the economic impact of tourism has been undeniable, it has not been without its problems. Despite providing important economic contributions to what are often developing nations, global tourism has also been one of the leading causes of environmental degradation and cultural loss (Kirtsoglou \& Theodossopoulos, 2004; Shahzalal, 2016). Island nations are especially vulnerable, as their ecosystems have often been transformed or even destroyed to make place for development projects (Perdikaris et al., 2020). Climate change has rendered many of Earth's environmental systems vulnerable, and this exposes people to factors that at first glance seem unrelated to warming temperatures and sea level rise. We see a rise in mosquito- and tick-borne diseases as global temperatures and seasonal rainfall that affect insect populations shift (Colarossi, 2020). The way people interact with nature - exploiting natural resources for housing, food, or other capitalist ventures from previously untapped sources - leads to exposure that can rapidly transmit pathogens through international trade or the flow of people for work or tourism, resulting in widespread introduction of disease to populations without immunity. This creates a new layer of decision making for island nations dependent on tourism, as they must weigh the cost-benefit analysis of disease spread and economic revenue versus the well-being of their people. Nevertheless, most island nations remain and will continue to remain dependent on tourism as an important part of their economy. The $90 \%$ drop in global tourism since the start of the COVID-19 pandemic has had a devastating economic - if not public health - effect on many island nations, and it remains to be seen how they will recover.

\section{Diaspora, remittances, and informal economies}

In the 20th and 21st centuries, “even before independence reached most of the region's territories, people from the Caribbean were migrating in large numbers in search of work, a better life, and to escape from small and constricting island societies" (Ferguson, 2003, p. 6). The livelihoods of migrants and their families are not necessarily bound to one location, and it is not unusual to move back and forth between the host country and the home country. Transnationalism, facilitated by electronic communications and fast transportation, sustains migration as an essential aspect of the Caribbean and this is indeed the case for both Barbuda and Puerto Rico. These migrations "reinforce and extend the scope of the transnational networks involving migrants and non-migrants $[. .$.$] this has the effect of facilitating future migration and perpetuating the high$ propensity for migration that exists in the region" (Thomas-Hope, 2002, p. 10).

Caribbean international migration is frequently seasonal and transnational, meaning the movement of people is complex and dependent on many factors such as availability of opportunities, or an individual's aim in migrating, be it educational, economic, or familial (Nurse, 2004 , p. 4). Because the migration flow in the Caribbean is not usually one-way, it is difficult to tease out from standard population data. Migration in the Caribbean is nuanced. At the individual and household level, migration in the Caribbean can be seen as a quest for financial and social capital. In Barbuda and Puerto Rico, family connections remain strong irrespective of an individual's location. When a person leaves the island for an extended time to pursue schooling, 
employment, or other opportunities, they do not lose their place in their community. Both Barbudan and Puerto Rican citizens were able to move freely for any reason to Antigua or mainland U.S., respectively, in pre-pandemic times. This is another reason the intra-island flow of people should be viewed separately from "immigration." In the case of Barbuda, the ease of moving to Antigua for work is seen less as migration and more along the lines of commuting.

Puerto Rican migration to other regions of the U.S. began in the first half of the 20th century when Puerto Ricans were recruited by the thousands to cut sugar cane in Hawai'i. Migratory movements between the island and continental U.S. intensified after WWII, a period (1946-1964) known as ‘The Great Migration' where 650,000 Puerto Ricans moved off-island (Ayala, 1996). Migration was facilitated by the increased availability of commercial flights, and through government sponsored programs, like the Farm Labor Program, which sent unemployed rural workers to the mainland to supply labor to the U.S. economy. Economic motivations fuel the Puerto Rican diaspora. According to the last U.S Census, almost half (44\%) of the population of the island lives in poverty - three times the rate in the continental U.S. (United States Census, 2019). Between 2010 and 2015, the population of Puerto Rico declined by 6.8\%; as a result, there are more Puerto Ricans living in the continental U.S. than on the island (Krogstad, 2016). Barbuda has also experienced a widespread migration. Currently, there are more Barbudans living in the U.S., Canada, and the United Kingdom than in Barbuda itself (U. S. Department of Commerce, 2022). The most recent dramatic population change in Barbuda was the forced evacuation of Barbudans to Antigua following Hurricane Irma in 2017 (Perdikaris et al., 2020). To date, out of the 1,700 people living on island prior to the hurricane, about 1,634 have returned, the rest choosing, for a variety of reasons, to stay in Antigua (Boger \& Perdikaris, 2019). Even so, those who have not returned maintain their connections to relatives by coming home for vacations, attending family gatherings, and by sending monies for the repair of their hurricanedamaged homes. While many migrants from both Barbuda and Puerto Rico chose the path of relocation for economic reasons, during the COVID-19 pandemic the two islands diverged in the behavior of connection between migrant and home. Barbuda severely restricted travel back and forth to Antigua. Many Barbudans who had contract or seasonal jobs in Antigua were required to stay in Barbuda as businesses adjusted to the pandemic mandates. Travel between the islands was allowed by the central government in Antigua only on rare occasions, and restricted travel to and from Barbuda did not allow for the economic infusion of goods and funds resulting from traditional family visits and gatherings, so support from those living and working off-island continued in the form of electronic remittances. These remittances take the form of direct economic assistance or the creation of informal local jobs, as many expatriate Barbudans build or repair houses with the intention of moving back to the island for their retirement. Monies sent home are used to move forward with these projects even though the people who own the buildings are not physically present. Remittances allow those who relocate to other regions to connect with their relatives, thus allowing them to hold their place in their community. In effect, they become a fiscal lifeline during economic and physical isolation.

With a much higher per capita income and receiving federal support in the form of nutritional assistance, housing subsidies, unemployment, retirement, and disability payments, Puerto Ricans do not rely on remittances to build their safety net (Duany, 2010). Puerto Ricans, 
however, still travelled in person, transiting between the island and the mainland (Aranda, 2007). Statistics show a sizable portion of the arrivals from the U.S. during the COVID-19 pandemic were people returning home to be with their families. Unlike tourists, these Puerto Ricans were not perceived as 'dangerous others'. While these welcome arrivals were subjected to public health monitoring to prevent the spread of COVID-19, the extent to which a public health system, weakened by years of economic cuts and mismanagement, was able to effectively monitor and isolate this population remains in question.

In times of austerity, islanders in both Puerto Rico and Barbuda have developed entrepreneurial and creative systems to increase economic resilience. Anthropologist Keith Hart (1973) coined the term "informal sector" to refer to those economic activities that generate income and/or capital but fall outside of formal (state-operated or official) income earning opportunities. These can range from marginal operations to larger enterprises, and are usually a direct result of growing unemployment and underemployment (K. Hart, 1973). Informal economies, partly initiated through remittances, are a significant force for communities to maintain and expand economic activity amid a crisis (Chen, 2012, p. 3).

As a region, the Caribbean has been dependent on informal economies since the colonial period, and while the informal sector looks quite different today, it remains the primary source of income for many of its residents. While most Caribbean economies are in the service sector, as is the case in the nation of Antigua and Barbuda, the reliance on informal economies is substantial (Mapp \& Moore, 2015). On a small island like Barbuda, informal economy is an important part of daily life. In addition to being one of the few sources of income, informal economy is an important "buffer against economic shocks for marginalized members of the society" (Mapp \& Moore, 2015). On average, scholars estimate that the informal sector makes up approximately 24\% of Antigua and Barbuda's overall GDP (Mapp \& Moore, 2015).

While Puerto Ricans benefited from the passage of The Coronavirus Aid, Relief, and Economic Security Act (popularly known as the CARES ACT) in 2020, this support was not enough for poor workers, already reeling from a protracted economic crisis. The COVID-19 pandemic has caused a surge in Puerto Rico's informal economy, with people being forced to work in-person jobs contributing to the spread of the virus. In an interview with The Weekly Journal, economist Joaquín Villamil said that "prior to the pandemic underground economic activity generated over $\$ 17$ billion approximately - or 30\% of the Gross Domestic Product of Puerto Rico" (Ramos-Segarra, 2020). Villamil went on to conclude that this upsurge in informal economy activities would not be temporary and created a greater issue for Puerto Rico's longterm recovery, as none of this generated income is taxed and cannot support the crumbling infrastructure (Ramos-Segarra, 2020). This shows that, during a global pandemic, informal economies present a new set of challenges that can have devastating effects on public health outcomes (Chen, 2012). The difference between the response of the two islands is one of scale. The number of residents in Barbuda (around 1,600) were in effect a pod, while that was not possible in Puerto Rico. 


\section{Conclusion}

Even though the islands of Barbuda and Puerto Rico have a shared history of colonization and dispossession at the periphery of the world system (Wallerstein, 1974), the differential impact of COVID-19 comes down to population density and community structure. We suggest that Puerto Rico could not isolate itself from the damaging economic and political influence of the U.S. and its failure to contain COVID-19. To date, the U.S. has one of the largest absolute number of cases and deaths anywhere in the world, with minority populations, particularly African Americans and Latinos, disproportionally affected (Rodriguez-Diaz et al., 2020). While the pandemic is always evolving, the strategy implemented by Barbuda - to severely restrict travel on and off island for any reason - has paid off. In comparison, Puerto Rico and Antigua, who have allowed tourism and a steady flow of people to the islands, have exhibited much higher levels of COVID-19 prevalence (Mallapaty, 2020).

Islands are in a particular position to manage pandemics because they are self-contained. Depending on their position, they can shut down if they have substantial resources. An island's ability to be resilient during a pandemic is linked to their dependence on a global economy, the ability for their informal economy to function supported by remittances from abroad, and the local authority to close their borders. Tourism is under much scrutiny because while the islands need the tourists to support the economy, tourism has become a danger to the local citizens. While in the case of Barbuda, tourism is a minor part of the island's economy, in Puerto Rico and Antigua it is the major economic driver. In the mono-economy of tourism, there is no contingency fund because the focus is on profit. Consequently, when tourism fails, or is even restricted, there is no way to pivot. In both situations, the governments are making important decisions about the economy while having to balance it against public health.

The COVID-19 pandemic has revealed how vulnerable communities that are reliant on tourism have become. Dependency on Western capitalism and the mono-economy of tourism trumping all other forms of economy treats islanders as expendable collateral damage and maintains the inequality of a colonial relationship. Service workers are deemed 'essential personnel', risking their lives daily to feed, clean, and change bedding in 'COVID-19 approved' hotels. The pandemic has shed new light on the reality of servitude to capitalism in the Caribbean. One of the takeaway messages from the lived experiences of this pandemic is that neocolonial economic models reliant on tourism and foreign development are flawed and short-sighted. Capitalist ideals defined by wealth and profit ignore sustainability and beg the question of what we, as people, are willing to sacrifice or risk for those temporal profits. This trajectory increases the vulnerability of island nations and actively denies resilience in the Caribbean. Throughout history, we have seen the cyclical series of events - occupation, depletion, abandonment — and this cycle is fully underway in the Caribbean now. Who will "save" the islands when the collapse becomes inevitable and irreversible? Barbuda survived its colonial encounter with this cycle, due to the strength of its ever-present community, but now finds itself standing at the center of troubling crossroads. While it has dodged the bullet of the pandemic thus far, as outside investors and Antiguan policymakers gain power and decisions are no longer in control of the community, 
it is in danger of suffering the same fate as Antigua and Puerto Rico. In times where judgement is clouded by profit, we need to step back and reexamine the consequences of destroying communities that are sustainable, instead of rushing to invest in exploitative ventures. We need to stand up and flip the model on its head by embracing community values that respect indigeneity, identity, and culturally informed use of resources rather than perpetuating the inequity created by a geography of pleasure. Let us learn from this paradigm-shifting pandemic to follow the lead of resilient communities by investing in economic diversification, education and the common good.

Authors' note: Since the time of writing, there have been a multitude of changes in responses as new COVID-19 variants emerge on Barbuda. As of October 2021, the Delta variant has inflicted a severe blow on Barbuda, whose initial response was to close the border, as described above but this strategy of isolation has begun to unravel. Bringing money from abroad has come with costs for the island in the form of rising case numbers, as well as deaths. The drastic imposition of a $100 \%$ vaccine mandate for those eligible is too little too late.

\section{Acknowledgements}

The authors would like to thank the citizens of Barbuda and Puerto Rico for welcoming them to their islands and sharing their knowledge with them. Warm thanks also go out to the present and past members of the Barbuda Council and the Barbuda Research Complex. This work would not have been possible without the help and support of Dr. Reg Murphy and Mr. Calvin Gore, Mr. Shaville Charles, and Mr. Dwight Finch. The work in Barbuda was supported by the Ann M. Stack Trust.

\section{References}

Antigua and Barbuda Tourism Authority. (2021). Antigua and Barbuda Travel Advisory. Retrieved May 1, 2021, from https://visitantiguabarbuda.com/travel-advisory/

Aranda, E. M. (2007). Emotional bridges to Puerto Rico: Migration, return migration, and the struggles for incorporation. Rowman \& Littlefield.

Ayala, C. J. (1996). The decline of the Plantation economy and the Puerto Rican migration of the 1950s. Latino Studies Journal, 7(1), 61-90.

Ayala, C. J., \& Bernabe, R. (2009). Puerto Rico in the American century: A history since 1898. University of North Carolina Press.

Barbuda Council. (2021a, January 7). PRESS RELEASE. We sadly informed the public, that Barbuda has recorded it's very first positive COVID19 case. However, the concerned individual is [Image attached] [Status update]. Facebook. https://www.facebook.com/BarbudaCouncilPR/photos/a.1879815312261006/2799057 $\underline{597003435 /}$ 
Barbuda Council. (2021b, February 21). PRESS RELEASE... PLEASE TAKE NOTE [Image attached] [Status update]. Facebook. https://www.facebook.com/BarbudaCouncilPR/photos/a.1879815312261006/2830686 $\underline{887173839}$

Boger, R., \& Perdikaris, S. (2019, February 11). After Irma, disaster capitalism threatens cultural heritage in Barbuda. NACLA. https://nacla.org/news/2019/02/12/after-irma-disastercapitalism-threatens-cultural-heritage-barbuda

Burnett, C. D., \& Burke, M. (2001). Foreign in a domestic sense: Puerto Rico, American expansion, and the Constitution. Duke University Press.

Centers for Disease Control and Prevention. (2021). COVID-19 in Antigua and Barbuda. Retrieved May 1, 2021, from https://wwwnc.cdc.gov/travel/notices/covid4/coronavirus-antigua-and-barbuda

Chen, M. (2012). The informal economy: Definitions, theories and policies [WIEGO Working paper no. 1]. Women in Informal Employment Globalizing and Organizing (WIEGO). https://www.wiego.org/sites/default/files/migrated/publications/files/Chen WIEGO WP1.pdf

Codrington Papers 1681-1944 Collection. National Archive of Antigua and Barbuda, Long Street, St. John's, Antigua.

Colarossi, J. (2020). Ticks and mosquitoes, infectious disease carriers, are expanding their range. The Brink. https://www.bu.edu/articles/2020/ticks-mosquitoes-infectious-disease-carriersexpanding-their-range/

Collins, M. (2008). Balancing the world economy: An interview with Ambassador Byron Blake, Deputy United Nations Permanent Representative for Antigua and Barbuda. Callaloo: A Journal of African Diaspora Arts and Letters, 31(4), 1291-1301. https://dx.doi.org/10.1353/cal.0.0259

Cruz-Cano, R., \& Mead, E. L. (2019, March 12). Excess deaths after Hurricane Maria in Puerto Rico. JAMA, 321(10), 1005. http://doi.org/10.1001/jama.2018.20861

Dietz, J. L. (2003). Puerto Rico: Negotiating development and change. Lynne Rienner.

Duany, J. (2017). Puerto Rico: What everybody needs to know. Oxford University Press.

Duany, J. (2010). To send or not to send: Migrant remittances in Puerto Rico, the Dominican Republic, and Mexico. The Annals of the American Academy of Political and Social Science, 630(1), 205-223. https://psycnet.apa.org/doi/10.1177/0002716210368111

Ferguson, J. (2003). Migration in the Caribbean: Haiti, the Dominican Republic and beyond. Minority Rights Group International. https://www.refworld.org/docid/469cbfaf0.html

Figueroa, L. A. (2005). Sugar, slavery, and freedom in nineteenth-century Puerto Rico. University of North Carolina Press.

First positive Covid-19 case recorded in Barbuda. (2021, January 8). Antigua Observer. https://antiguaobserver.com/first-positive-covid-19-case-recorded-in-barbuda/

García, C., Rivera, F. I., Garcia, M. A., Burgos, G., \& Aranda, M. P. (2020). Contextualizing the COVID-19 era in Puerto Rico: Compounding disasters and parallel pandemics. The Journals of Gerontology: Series B, 76(7), e263-267. https://doi.org/10.1093/geronb/gbaa186 
Garriga-López, A. M. (2020). Compounded disasters: Puerto Rico confronts COVID-19 under US colonialism. Social Anthropology / Anthropologie Sociale, 28(2), 269270. https://doi.org/10.1111/1469-8676.12821

Garriga-López, A. M. (2018). A school of addicts: The coloniality of addiction in Puerto Rico. In C. McGranahan \& J. F. Collins (Eds.), Ethnographies of U.S. empire (pp. 93-111). Duke University Press.

Goldstein, M. B., \& Engwall, D. (1992). The politics of prevention. Journal of Health E Social Policy, 3(3), 69-83. http://doi.org/10.1300/J045v03n03 05

Gonzalez-Scollard, E. (2008). Raising Cane: People and the environment in 19th-century Antigua, West Indies (Doctoral dissertation). The Graduate Center, City University of New York.

Hart, K. (1973). Informal income opportunities and urban employment in Ghana. The Journal of Modern African Studies, 11(1), 61-89. https://www.jstor.org/stable/159873

Hart, S., Sedona, C., \& Soroka, S. (2020). Politization and polarization in COVID-19 news coverage. Science Communication, 679-697. https://doi.org/10.1177\%2F1075547020950735

Johns Hopkins University and Medicine. (2021a). Antigua and Barbuda. Coronavirus Resource Center. Retrieved March 15, 2021, from https://coronavirus.jhu.edu/region/antiguaand-barbuda

Johns Hopkins University and Medicine. (2021b). Puerto Rico. Coronavirus Resource Center. Retrieved March 15, 2021, from https://coronavirus.jhu.edu/region/us/puerto-rico

Kane, D. D. (2018). Mortality in Puerto Rico after Hurricane Maria. New England Journal of Medicine, 379(17), e30. https://doi.org/10.1056/nejmc1810872

Kirtsoglou, E., \& Theodossopoulos, D. (2004). They are taking our culture away: Tourism and cultural commodification in the Garifuna community of Roatan. Critique of Anthropology, 24(2), 135-157. https://doi.org/10.1177\%2F0308275X04042650

Klein, N. (2007). The shock doctrine: The rise of disaster capitalism. Metropolitan Books.

Krogstad, M. J. (2016, March 24). Historic population losses continue across Puerto Rico. Pew Research Center. http://www.pewresearch.org/fact-tank/2016/03/24/historic-population-lossescontinue-across-puerto-rico/

LeBrón, M. (2012). Neocolonial policing in Puerto Rico. NACLA Report on the Americas, 45, 12-16. http://doi.org/10.1080/10714839.2012.11722106

Look, C., \& Brown, M. (2007). Field report survey on Barbuda. Department of Anthropology, Brooklyn College, City University of New York.

Mallapaty, S. (2020). What the cruise-ship outbreaks reveal about COVID-19. Nature, 580, 18. https://doi.org/10.1038/d41586-020-00885-w

Mapp, T., \& Moore, W. (2015). The informal economy and economic volatility. Macroeconomics and Finance in Emerging Market Economies, 8(1-2), 185-200. http://doi.org/10.1080/17520843.2014.969291

Mintz, S. (1985). Sweetness and power: The place of sugar in modern history. Viking.

Mintz, S. (1974). Worker in the cane: A Puerto Rican life history. Norton. 
Miranda, M. (2020, March 15). Puerto Rico Governor announces curfew amid outbreak. Caribbean Business. https://caribbeanbusiness.com/puerto-rico-governor-announces-curfew-amidoutbreak/

Murphy, C. (2021, March 12). Puerto Rico sees a surge in tourism - and a rise in aggressive tourist behavior. The Guardian. https://www.theguardian.com/world/2021/mar/12/puerto-rico-tourists-aggressivebehavior-coronavirus

Murphy, R. (1999). From inland to the sea: Archaeological investigations along the ancient watercourses in Antigua. Proceedings of the 18th International Conference of Caribbean Archaeology (pp. 119-123).

Mykhalovkly, E., \& French, M. (2020). COVID-19, public health, and the politics of prevention. Sociology of Health and Illness, 42(8), e4-e15. https://doi.org/10.1111/1467-9566.13192

Newsom, L. A., \& Pearsall, D. (2003). Trends in Caribbean archaeobotany. In P. Minnis (Ed.), People and plants in the ancient Eastern North America (pp. 347-412). Smithsonian Institution Press.

Newsom, L. A., \& Wing, E. S. (2004). On land and sea. University of Alabama Press.

Pan American Health Organization. (2021). Antigua and Barbuda. Retrieved May 1, 2021, from https://www.paho.org/en/antigua-and-barbuda

Perdikaris, S., \& Hejtmanek, K. R. (2020). The sea will rise, Barbuda will survive: Environment and time consciousness. Ecocene: Cappadocia Journal of Environmental Humanities, 1(2), 92108. https://doi.org/10.46863/ecocene.6

Perdikaris, S., Bain, A., Boger, R., Grouard, S., Faucher, A. M., Rousseau, V., Persaud, R., Noel, S., Brown, M., \& Medina-Triana, J. (2017). The effects of climate change on the small island of Barbuda, Lesser Antilles. In T. Dawson (Ed.), Cultural heritage under threat (pp. 138-148). Oxford University Press.

Perdikaris, S., Boger, R., \& Ibrahimpasic, E. (2020). Seduction, promises and the Disneyfication of Barbuda post Irma. TRANSLOCAL. Contemporary Local and Urban Cultures, 5. http://translocal.cm-funchal.pt/2019/05/02/revista05/

Perdikaris, S., Grouard, S., Hambrecht, G., Hicks, M., Mebane-Cruz, A., \& Pershaud, R. (2013). The caves of Barbuda's Eastern coast: Long term occupation, ethnohistory and ritual. Caribbean Connections, 3(1), 1-9. https://digitalcommons.unl.edu/global/27/

Pico, F. (2006). History of Puerto Rico: A panorama of its people. Markus Wiener.

Potter, A. E., Chenoweth, S., \& Day, M. (2017). Antigua and Barbuda. In C. Allen (Ed.), Landscapes and landforms of the Lesser Antilles. World geomorphological landscapes. Springer.

Potter, A. E., \& Sluyter, A. (2010). Renegotiating Barbuda's commons: Recent changes in Barbudan open-range cattle herding. Journal of Cultural Geography, 27(2), 130-132. https://doi.org/10.1080/08873631.2010.494404

Ramos-Segarra, C. (2020, September 3). The other face of formal economy: The rise in informal activities would assuage the impact of COVID-19. The Weekly Journal. https://www.theweeklyjournal.com/business/the-other-face-of-formaleconomy/article e182ae1a-edf3-11ea-8d44-778df6e068f2.html 
Reuters. (2021). COVID-19 Tracker: Antigua and Barbuda. Retrieved May 1, 2021, from https://graphics.reuters.com/world-coronavirus-tracker-and-maps/countries-andterritories/antigua-and-barbuda/

Rivera-Ramos, E. (2001). The legal construction of identity: The judicial and social legacy of American colonialism in Puerto Rico. American Psychological Association.

Rodriguez-Diaz, C. E., Guilamo-Ramos, V., Mena, L., Hall, E., Honermann, B., Crowley, J. S., Baral, S., Prado, G. J., Marzan-Rodriguez, M., Beyrer, C., Sullivan, P. S., \& Millett, G. A. (2020). Risk for COVID-19 infection and death among Latinos in the United States: Examining heterogeneity in transmission dynamics. Annals of Epidemiology, 52(46-53), e2. https://doi.org/10.1016/j.annepidem.2020.07.007

Romano, J. L. (2020). Politics of prevention: Reflections from the COVID-19 Pandemic. Journal of Prevention Health Promotion, 1(1), 34-57. http://doi.org/10.1177/2632077020938360

Setser, B., \& Maruach, S. (2020). The Puerto Rican economy. In R. E. Looney (Ed.), Handbook of Caribbean economies. Routledge.

Shahzalal, M. (2016). Positive and negative impacts of tourism on culture: A critical review of examples from the contemporary literature. Journal of Tourism, Hospitality and Sports, 20, 30-34. https://core.ac.uk/download/pdf/234696865.pdf

Sheller, M. (2020). Reconstructing tourism in the Caribbean: Connecting pandemic recovery, climate resilience and sustainable tourism through mobile justice. Journal of Sustainable Tourism. https://doi.org/10.1080/09669582.2020.1791141

Thomas-Hope, E. M. (2002). Caribbean migration. University of the West Indies Press.

Thomas, L. (2010). Puerto Rican citizen: History and political identity in twentieth-century New York City. University of Chicago Press.

Thompson, L. (2010). Imperial archipielago: Representation and rule in the insular territories under U.S. Dominion after 1898. University of Hawai'i Press.

U.S. Department of Commerce. (2022). Quick facts: Puerto Rico. United States Census Bureau. Retrieved February 14, 2020, and March 15, 2021, from https://www.census.gov/quickfacts/PR

Valencia, M., Becerra, J. E., Reyes, J.C., \& Castro, K. G. (2020). Assessment of early mitigation measures against COVID-19 in Puerto Rico: March 15-May 15, 2020. PLoS ONE, 15(10), e0240013. https://doi.org/10.1371/journal.pone.0240013

Villanueva, J., Coban, M., \& Rodriguez, F. (2018). San Juan, the fragile city: Finance capital, class, and the making of Puerto Rico's economic crisis. Antipode, 50(5), 1415-1437. https://doi.org/10.1111/anti.12406

Vuletin, G. (2008). Measuring the informal economy in Latin America and the Caribbean [IMF Working Paper No. 08/102]. Brookings Institution.

Wallerstein, I. (1974). The modern world system I: Capitalist agriculture and the origins of the European world-economy in the sixteenth century. Academic Press. 
Sophia Perdikaris et al.

Watters, D., Donahue, J., \& Stuckenrath, R. (1992). Paleoshorelines and the prehistory of Barbuda, West Indies. In L. L. Johnson \& M. Stright (Eds.), Paleoshorelines and prehistory: An investigation of method (pp. 15-52). CRC Press.

World Travel and Tourism Council. (2021). Economic impact reports. Retrieved May 1, 2021, from https://wttc.org/Research/Economic-Impact 